\title{
Phase and structure characteristics of recycled AIZn10Si8Mg cast alloy
}

Ing. Emília Ďuriníková, prof. Ing. Eva Tillová, PhD., Ing. Mária Chalupová

Department of Materials Engineering, Faculty of Mechanical Engineering, University of Žilina

Univerzitná 8215/1, 010 26, Žilina, Slovak Republic. emilia.durinikova@fstroj.uniza.sk

The contribution describes effect of the temperature $\left(20-400^{\circ} \mathrm{C}\right)$ on structure and mechanical properties (Brinell hardness and bending impact toughness) of the recycled AIZn10Si8Mg cast alloy. AlZn10Si8Mg cast alloy are used for engine and vehicle constructions, hydraulic unit and mould making without heat treatment. Improved mechanical properties are strongly dependent upon the morphologies, type and distribution of the phases, which are in turn a function of alloy composition and cooling rate. A combination different analytical techniques (light microscopy upon blackwhite and colour etching, scanning electron microscopy (SEM) upon deep etching, energy dispersive X-ray analysis (EDX) and HV 0.01 microhardness measurement) were therefore been used for the identification of the various phases. It is therefore necessary to study their structure and impact of intermetallic phases on the mechanical properties of aluminium alloys. The paper evaluates change of absorbed energy of impact at different temperature and the effect of structural change and hardness change in alloy during the test. The experiment was realized out using Charpy hammer and Brinell hardness tester.

Keywords: recycled aluminium cast alloy, SEM, intermetallic phases, Brinell hardness, bending impact toughness

Acknowledgements

This work has been supported by Scientific Grant Agency of Ministry of Education of Slovak republic, No1/0841/11, KEGA 220-009ŽU-4/2010 and bilateral project SK-CZ-0086-09.

\section{References}

[1] DAS, K. S.: Designing Aluminum Alloys for a Recycle-Friendly World. Materials Science Forum, 2006, Vols. 519521, pp. 1239-1244. ISSN 0255-5476.

[2] SENČÁKOVÁ, L., VIRČíKOVÁ, E.: Life cycle assessment of primary aluminium production, Acta Metallurgica Slovaca, vol. 13, 3, 2007, pp. 412-419. ISSN 1338-1156.

[3] www.sag.at

[4] TILlOVÁ, E., CHALUPOVÁ, M.: Štruktúrna analýza zliatin Al-Si, EDIS, Žilina, 2009, 191s. (in Slovak). ISBN 97880-554-0088-4.

[5] MICHNA, Š.; LUKÁČ, I. a kol.; Encyklopedie hliníku. 2005, Adin s.r.o. Prešov. in Czech, p. 700, ISBN 80-89041-884.

[6] VAJSOVA, V.; MICHNA, Š.; Optimalizace homogenizačního žíháni slitiny AlZn5,5Mg2,5Cu1,5 In. Strojirenská technologie, 2010, roč. XV, č. 3 p. 6-11.

[7] SEIFEDDINE, S.: The influence of Fe on the microstructure and mechanical properties of cast Al-Si alloys, Literature review - Vilmer project, 2007, Jönköping University, Sweden.

[8] CAO, X., CAMPBELL, J.: The Solidification Characteristics of Fe-Rich Intermetallics in Al11.5Si0.4Mg cast alloys, Metallurgical and Materials Transactions A, 35A, 2004, pp. 1425-1435. ISSN 1073-5623.

[9] APELIAN, D.: Aluminum Cast Alloys: Enabling Tools for Improved Performance, World Wide Report, published by NADCA, 2009.

[10] www.alurheinfelden.com

[11] ĎURINÍKOVÁ, E., TILLOVÁ, E., CHALUPOVÁ, M.: Effect of the temperature on mechanical properties of the recycled AlZn10Si8Mg cast alloy, Chapter 4 in monograph: Quality improvement of construction materials, 2011, Zaborze.

[12] WECK, E., LEISTNER, E.: Metallographic Instructions for Colour Etching by Immersion, Part III, Deutscher Verlag für Schweisstechnik-GmbH, 1986, Düsseldorf.

[13] TILLOVÁ, E., ĎURINÍKOVÁ, E,. CHALUPOVÁ, M,: Characteratization of phases in secondary AlZn10Si8Mg cast alloy, Materiálové inžinierstvo, vol. 18, 2011, pp. 1-7. ISSN 1335-0803. 
[14] SHABESTARI, S.G.: The effect of iron and manganese on the formation of intermetallic compounds in aluminumsilicon alloys, Materials Science and Engineering A 383, 2004, pp. 289-298. ISSN 0921-5093

[15] ĎURINÍKOVÁ, E. TILlOVÁ, E., CHALUPOVÁ, M.: Vplyv teploty na štruktúru a rázovú húževnatost' zliatiny AlZn10Si8Mg, In: SEMDOK 2011: 15th international of PhD. students' seminar, Žilina, 2011, pp. 91-94, (in Slovak). ISBN 978-80-554-0315-1.

Paper number: M201103

Manuscript of the paper recieved in 2011-08-01. Final paper including reviews reminders respect recieved to editors in 2011-11-29. The reviewers of this paper: Prof. Iva Nova, MSc., Ph.D. and Assoc. Prof. Pavel Novak, MSc., Ph.D. 